\title{
Isolation and Identification of Cytotoxic and Biological Active Toxin from the Puffer Fish Arothron stellatus
}

\author{
Anguchamy Veeruraj ${ }^{1,4}$, Sampath Renuga Pugazhvendan², Thipramalai Thankappan Ajithkumar ${ }^{3}$ \\ and Muthuvel Arumugam ${ }^{1}$ \\ ${ }^{1}$ Centre of Advanced Study in Marine Biology, Faculty of Marine Sciences, Annamalai University, Tamilnadu, India \\ ${ }^{2}$ Department of Zoology, DDE-Wing, Annamalai University, Tamilnadu, India \\ ${ }^{3}$ National Bureau of Fish Genetic Resources, Indian Council of Agricultural Research, Uttar Pradesh, India \\ ${ }^{4}$ Centre for Ocean Research, SU-NIOT Joint Initiative Research Centre, Rajiv Gandhi Salai, Sathyabama University, Tamilnadu, India
}

(Received November 12, 2015; Revised April 19, 2016; Accepted May 20, 2016)

\begin{abstract}
This study is to investigate the biological, biochemical and cytotoxic effects of puffer fish (Arothron stellatus) toxin extracts under in-vitro condition. Extracted toxins from various organs of puffer fish were purified by using active charcoal column, and Bio-gel-P2 column chromatography. The lethality of toxin was tested in crabs, which consists of neurotoxic compounds. The degree of the brine shrimp lethality assay was found directly proportional to the concentration of the toxin extracts, which was well supported by hemolytic assay. The experimental results suggested that the gonad was found higher toxins than the liver and muscles. The mortality rate of brine shrimp nauplii was increased with the raise of concentrations of toxin level. Among the different doses and time dependent cytotoxic effect of human cervical carcinoma (HeLa) cells were showed $4.0 \mu \mathrm{g} / \mathrm{mL}$ of toxin, which was effectively inhibited cancer cell proliferation. HPLC and TLC analysis was revealed that the A. stellatus toxin contains tetrodotoxin (TTX), related compounds 4-epi TTX and anhydro-TTX. The present results suggested that the $A$. stellatus contain TTX as a major and anh-TTX as a minor toxin. It could be the potential candidate in the field of anticancer drug discovery against human cervical cancer cells. The present data is confirming that the puffer fish toxin as an interesting source of novel bioactive natural compounds with potent applications in pharmacology.
\end{abstract}

Key words: Puffer fish, Arothron stellatus, Toxin, Lethality, HeLa cells, Cytotoxicity

\section{INTRODUCTION}

Cancer causes an estimated one in eight deaths worldwide (1), which is leading high casualty of the globe. A diverse group of diseases characterized by the uncontrolled proliferation of anaplastic cells tends to invade surrounding tissues and metastasize to other tissues and organs (2). Hence, development of new anticancer drugs represents today's one of the most important research areas. An analysis of the number of chemotherapeutic agents and their sources indicate over $74.8 \%$ of the approved drugs are derived from

Correspondence to: Anguchamy Veeruraj, Centre of Advanced Study in Marine Biology, Faculty of Marine Sciences, Annamalai University, Parangipettai - 608 502, Tamilnadu, India E-mail: anguveeruraj@gmail.com, mamnplab@gmail.com

This is an Open-Access article distributed under the terms of the Creative Commons Attribution Non-Commercial License (http:// creativecommons.org/licenses/by-nc/3.0) which permits unrestricted non-commercial use, distribution, and reproduction in any medium, provided the original work is properly cited. natural compounds (3). Unfortunately, drugs which are used for cancer therapy, such as doxorubicin and cisplatin (4), are having severe adverse effects, which also normal cells and tissues (5). Chemoprevention entails the use of specific natural dietary or synthetic agents to thwart cancer development and progression (6).

Many potent natural products have displays the effective anticancer activities from the marine environment. Naturederived pharmaceuticals including marine-derived bioactive products have been draw a great deal of attention from both the scientific community and the general public due to their demonstrated ability to suppress cancers. Indeed, in early $1990 \mathrm{~s}$, there has been a dramatic increase in the number of preclinical anticancer lead compounds from marine sources, which have entered into human clinical trials (7). Therefore, the research and development of more effective and less toxic drugs become a necessary by the pharmaceutical industry. Therefore, the marine natural products are emerging as an alternative source for new drugs and play an important role in the treatment of human diseases such as 
cancer and tuberculosis (TB).

Several anticancer agents are derived from marine sources, which are entered preclinical and clinical trials to display cytotoxic activity against various tumor types (8). In this study, the special attention is pay to this disease is based upon the fact that cancer remains one of the leading causes of death in developing countries causing around two million deaths annually (9). Therefore, the investigation of alternative treatments for this disease is much needed.

Tetrodotoxin (TTX) is one of the most potent marine neurotoxin, named after the order of fish where it is most commonly associated, the Tetraodontiformes (tetras-four and odontos-tooth), or the tetraodon puffer fish. This toxin is predominantly isolated from the ovary and liver of puffer fish (10). Puffer fish are initially considering the only animals that contain TTX, later this compound has been reported from a taxonomically diverse range of marine and terrestrial organisms from 14 different phyla (11). The Tetraodontidae family has been mainly distributed in tropical and subtropical areas of the Atlantic, Indian and Pacific regional waters. A number of species have been assigned to new genera in recent years; presently, 29 genera and 187 named species are recognized (12).

Veeruraj et al. (13) have reported in nine species of marine puffers in the order tetraodontiformes and family tetraodontidae along the Parangipettai coast, Southeast coast of India in Tamilnadu. The amount of TTX in the puffer fish is species specific and varies among different organs in different seasons (14). TTX is originally produced by marine bacteria, and distributed over a wide variety of animals other than puffer fish, including gobies, blue-ringed octopuses, carnivorous gastropods, starfish, toxic crabs, horseshoe crabs, dinoflagellates, alga, arthropods, flat worms, and ribbon worms (15). In the present study, the level of toxins are extracted from marine puffer fish (Arothron stellatus) from various organs such as muscle, liver and gonads to identify its cytotoxicity effect on cultured human HeLa cell line, normal human erythrocytes, effects of toxicity against Artemia salina nauplii, sea shore crab Ocypode macrocera, and finally isolated toxin were characterized through HPLC and TLC techniques.

\section{MATERIALS AND METHODS}

Collection of specimens. The puffer fish (Arothron stellatus) was collected from Parangipettai (Lat. $11^{\circ} 29 \mathrm{~N}$ long. $79^{\circ} 46^{\prime} \mathrm{E}$ ) fish landing center and washed 3 times with distilled water. 20 grams of each organ such as muscle, ovary and liver were dissected out subsequently, weighed under aseptic conditions and frozen at $-20^{\circ} \mathrm{C}$ until used.

Isolation and purification of toxin. Each organ (muscles, gonads and liver) was homogenized separately with 1 volume of $1 \%$ acetic acid solution. Each homogenate was centrifuged at $4500 \mathrm{rpm}$ for $15 \mathrm{~min}$ and the supernatant was collected and washed twice with the same volume of $1 \%$ acetic acid. Each combined extract was concentrated separately under reduced pressure and defatted with $\mathrm{CH}_{2} \mathrm{Cl}_{2}$. The aqueous layer obtained was concentrated, adjusted to $\mathrm{pH} 4 \sim 5$ with $1 \mathrm{~N} \mathrm{NaOH}$ solution, and then treated with activated charcoal. The adsorbed toxin was eluted with 3 volumes of $1 \%$ acetic acid in $20 \%$ ethanol and the eluted sample was combined and evaporated under vacuum pump. Further purification was carried out in according to the methods of Kotaki et al. (16), by gel filtration using a column $\left(2.4 \times 120 \mathrm{~cm}^{2}\right)$ packed with Bio-Gel P-2 (Bio-Rad Laboratories, Richmond, CA, USA). Elution of the toxin was carried out with $0.03 \mathrm{~N}$ acetic acid at a flow rate of $60 \mathrm{~mL} / \mathrm{hr}$; then the toxicity of collecting fractions was determined by the bioassay.

Toxicity test. The acute toxicity study was carried out for the extracted toxin using adult sea shore crabs (Ocypode macrocera) (total body weight, $10 \sim 20 \mathrm{~g}$ ) and $0.1 \mathrm{~mL}$ of the toxin extract was injected into the junction of the body and third walking (chelate) leg of the crabs. The lethal dose $\left(\mathrm{LD}_{50}\right)$ was determined according to Lehman (17), with slight modification. To determine the $\mathrm{LD}_{50}$ values, ten crabs were injected with different concentration $(0.2,0.4$, $0.6,0.8$ and $1.0 \mathrm{mg} / \mathrm{mL}$ ) of the toxin extracts and observed for $1 \mathrm{hrs}$. Positive reactions were observed as tetanic contractions of the extremities of the sea shore crab and a triplicate of each concentration was used.

Hemolytic activity. The hemolytic activity of the toxin extracts on human erythrocytes were evaluated by using washed erythrocytes (RBCs), obtained from the peripheral blood (A \& B positive) of a healthy volunteer. The blood was centrifuged, and the serum and upper layer of white blood cells (Buffy coat) were removed and subsequent erythrocytes were washed 3 times in nine volumes of sterile saline $(\mathrm{NaCl})$ solution $(0.85 \%)$. After each washing, cells were centrifuged at $3000 \mathrm{rpm}$ for $5 \mathrm{~min}$ and the supernatant was discarded. The finally pellet was diluted $1: 9(\mathrm{v} / \mathrm{v})$ in sterile saline solution $(0.85 \%)$ and then in $1: 24(\mathrm{v} / \mathrm{v})$ sterile Dulbecco's phosphate buffer saline (D-PBS), $\mathrm{pH} 7.0$ containing $0.5 \mathrm{mM}$ boric acid and $1 \mathrm{mM}$ calcium chloride and brought to a final concentration of $5 \%(\mathrm{v} / \mathrm{v})$. For hemolysis assay, $100 \mathrm{~mL}$ of each extract was mixed with equal volume of erythrocytes suspension, and the mixture incubated for $60 \mathrm{~min}$ at $37^{\circ} \mathrm{C}$. The remaining unlysed cells were pelleted by $5 \mathrm{~min}$ centrifugation at $10,000 \mathrm{rpm}$ for $15 \mathrm{~min}$. Hemoglobin content of the supernatants was then evaluated spectrophotometrically at $540 \mathrm{~nm}$. The hemolytic activity of at least $10 \%$ hemolysis has been considered and the average value from triplicate assays was calculated. For negative and positive controls, RBCs in PBS $\left(\mathrm{A}_{\text {blank }}\right)$ and in $0.1 \%$ Triton X-100 ( $\left.\mathrm{A}_{\text {triton }}\right)$ was used, respectively. The percentage 
of hemolysis was calculated according to the equation (18).

$$
\% \text { hemolysis }=100 \times\left[\left(\mathrm{A}_{\text {sample }}-\mathrm{A}_{\text {blank }}\right) /\left(\mathrm{A}_{\text {triton }}-\mathrm{A}_{\text {blank }}\right)\right]
$$

Brine shrimp lethality assay (BSLA). The toxic effect against Artemia salina nauplii was tested followed by Meyer et al. (19) with minor modifications. Briefly, dried cysts of $A$. salina (Ocean Star International (O.S.I), Utah,

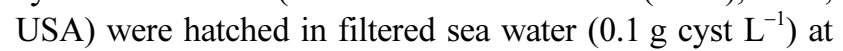
$27^{\circ} \mathrm{C}$ under continuous illumination and aeration. After $48 \mathrm{hr}$ of incubation, the $A$. salina nauplii were collected and 10 individuals were transferred to each well containing $50 \mu \mathrm{L}$ of filtered $(0.22 \mathrm{~mm})$ sea water (FSW) and $50 \mu \mathrm{L}$ toxin extract in different concentration of $0.2,0.4,0.6,0.8$ and $1.0 \mathrm{mg} / \mathrm{mL}$. The culture plates were incubated at $27^{\circ} \mathrm{C}$ in darkness and the number of dead larvae in each well was counted after $6 \mathrm{hr}$ (acute toxicity) and $24 \mathrm{hr}$ (chronic toxicity). Potassium dichromate $\left(\mathrm{K}_{2} \mathrm{Cr}_{2} \mathrm{O}_{7} ; 10 \sim 1000 \mathrm{ppm}\right)$ and Milli-Q water were used as a positive and negative control, respectively. Results are presented as percentage of mortality \pm standard deviation (SD) and $\mathrm{LC}_{50}$ value was estimated using the Probits statistical method (20). The percentage mortality of brine shrimp nauplii was determined from the number of dead nauplii and higher than $75 \%$ was considered as high mortality.

\section{Anticancer activity.}

Cell culture and In vitro cytotoxicity assay using [3H] thymidine Incorporation: Human cervical carcinoma (HeLa cells) was cultured and maintained in F-12 Dulbecco's Modification of Eagle's Meduim (DMEM) containing supplement of $10 \%$ fetal calf serum (FCS), amphotericin $(3 \mu \mathrm{g} / \mathrm{mL})$, gentamycin $(400 \mu \mathrm{g} / \mathrm{mL})$, streptomycin $(250 \mu \mathrm{g} /$ $\mathrm{mL})$ and penicillin $(250 \mathrm{Units} / \mathrm{mL})$ in a carbon dioxide incubator at $5 \% \mathrm{CO}_{2}$. In a 24 well plate $\left[{ }^{3} \mathrm{H}\right]$ thymidine ( $1 \mu \mathrm{ci} / \mathrm{mL}$ of medium) was added to the medium in which the cell line was already maintained. $20 \mu \mathrm{L}$ of different concentration $(2,4$ and $8 \mu \mathrm{g} / \mathrm{mL})$ of the puffer fish toxin was added to the cells and the same volume of buffer was added to the control well. The cultures were trypsinized at the desired time points, washed sequentially with $10 \%$ and $5 \%$ tricholoroacetic acid and solubilised in $0.1 \%$ sodium hydroxide and $0.025 \%$ sodium dodecyl sulphate solution. The radioactivity of the samples were measured in the Packard, Top Count $\mathrm{NXT}^{\mathrm{TM}}$ Liquid scintillation counters and expressed as cpm/mg protein. From the above experiment an appropriate dose is selected and added to human lymphocytes (purchased from Sigma -Aldrich Co., St. Louis, MO, USA) to check the effect on normal cells.

Determination of cell viability by MTT assay: The effects of puffer fish toxin on the proliferation of HeLa cells were measured by using the MTT (3-(4, 5-dimethylthiazol2-yl) -2, 5-diphenyl tetrazolium bromide) assay (21). HeLa cells $\left(1 \times 10^{4}\right.$ cells $\left./ \mathrm{mL}\right)$ were incubated in 96 wells plate in the presence and absence of toxin $(3 \mu \mathrm{g} / \mathrm{mL})$ for different time points $(0,12,24,36$ and $72 \mathrm{hr})$. At the required time point $50 \mu \mathrm{L}$ of supernatant was aspirated, added to another well and mixed with $50 \mu \mathrm{L}$ of the substrate buffer containing MTT dye. The microplate was incubated for $3 \mathrm{hr}$ at 27 to $37^{\circ} \mathrm{C}$ in $5 \% \mathrm{CO}_{2}$ and care was taken to keep the samples protected from light. After $3 \mathrm{hrs}$ incubation $100 \mu \mathrm{L} / \mathrm{well}^{-1}$ of the stop solution dimethyl sulfoxide (DMSO) was added and the absorbance was read on a microplate reader (ELISA plate Reader- Bio-Rad, Hercules, CA, USA) at $490 \mathrm{~nm}$. Raw absorbance readings were used to calculate the percentage cell death compared to that released by triton X-100 detergent. Percentage of cell death was calculated as,

$$
\begin{aligned}
& \text { [(values from experimental condition }) \\
& -(\text { values from untreated control })] / \\
& {[(\text { values from triton treated wells })} \\
& -(\text { values from untreated control })] \times 100 .
\end{aligned}
$$

Each experiment was repeated six times to ensure consistency.

\section{Detection of apoptosis:}

Propidium iodide staining; Toxin treated HeLa cells were incubated at $37^{\circ} \mathrm{C}$ for $24 \mathrm{hrs}$ in a 6 well plate and following the incubation cells were trypsinised and collected in microcentrifuge tubes. Subsequently cells were resuspended in $50 \mu \mathrm{L}$ of PBS and $5 \mu \mathrm{L}$ of RNase $(1 \mathrm{mg} / \mathrm{mL})$ and $5 \mu \mathrm{L}$ of Propidium Iodide $(25 \mu \mathrm{g} / \mathrm{mL}$ in PBS) was added and incubated at $37^{\circ} \mathrm{C}$ for an hour. Fluorescence was excited with an Argon ion laser at $488 \mathrm{~nm}$ and visualized under Nikon Fluorescence micro-scope.

Thin-layer chromatography. The purity of the toxin was checked by thin layer chromatography (TLC) as described by Nakamura and Yasumoto (22) with slight modification. Briefly, TLC assay was performed on silica gel $60-\mathrm{F}_{254}$ precoated TLC Aluminium plates $(10 \times 10 \mathrm{~cm} ; 0.25 \mathrm{~mm}$ layer thickness) (Merck, Darmstadt, Germany) with the n-butanol : acetic acid: water $(2: 1: 1 \mathrm{v} / \mathrm{v})$ solvent system. The developed toxins were visualized as a yellow or blue fluorescent spot under UV light $(365 \mathrm{~nm})$ after the plate was sprayed with $10 \% \mathrm{KOH}$, followed by heating at $110^{\circ} \mathrm{C}$ for $10 \mathrm{~min}$.

High-performance liquid chromatography. Freshly extracted puffer fish toxin was quantified in $20 \mathrm{~mL}$ of aliquots on a reverse phase high performance liquid chromatography (HPLC) system by modifying the procedures of Hanifin et al. (23). Samples were eluted with an isocratic gradient of $3.0 \%$ by volume acetonitrile, $0.97 \%$ by weight heptafluorobutyric acid, and $0.29 \%$ by volume of acetic acid. The elute from the column was continuously mixed with an equal volume of $4 \mathrm{~mol} / \mathrm{L}$ ammonium hydroxide buffer $\left(\mathrm{pH} \mathrm{5.0)}\right.$ and heated in a reaction coil at $110^{\circ} \mathrm{C}$. The toxin was detected with a fluorescence detector, monitoring the fluorescence at $510 \mathrm{~nm}$ with $365 \mathrm{~nm}$ excitation. Analy- 
ses were separated with a Synergi $4 \mu \mathrm{m}$ Hydro-RP $80 \mathrm{~A} \mathrm{C}_{18}$ column $(250 \times 4.6 \mathrm{~mm}$, Phenomenex, CA, USA). A Shimadzu LC- 10ADvp module provides a primary flow rate of $0.5 \mathrm{~mL}$ per min for the mobile phase and a Beckman 110A provide a secondary flow rate of $0.9 \mathrm{~mL}$ per min of $5 \mathrm{~N}$ sodium hydroxide for mixing post-column. The mixture was sent to a Pickering CRX 400 reactor at $130^{\circ} \mathrm{C}$ for derivatization of toxin into fluorescent breakdown products. A Hewlett Packard 3390A Integrator recorded the chromatographs and calculated peak areas. Toxins were identified by comparison of their retention times $(\mathrm{Rt})$ with that of the standard tetrodotoxins (TTX).

Statistical analysis. All the values are expressed as means \pm S.D. of 6 repeats in each group. Data within the groups was analyzed using one-way analysis of variance (ANOVA) followed by Duncan's Multiple Range Test (DMRT) using Statistical Package for the Social Sciences version 16.0 .

\section{RESULTS}

Yield and toxicity of puffer fish toxin. The amount of lyophilized crude toxin from A. stellatus organs of muscle, ovary and liver were estimated as 12.50, 18.35 and 14.45 $\mathrm{gm} / \mathrm{kg}$, respectively. The results of the $\mathrm{LD}_{50}$ test showed that $34.69 \pm 0.11 \mu \mathrm{g} / \mathrm{kg}$ of puffer fish ovary toxin was sufficient to kill $50 \%$ of the crabs, and followed by the liver and muscles, whose $\mathrm{LD}_{50}$ values were $42.84 \pm 0.28 \mu \mathrm{g} / \mathrm{kg}$ and $45.42 \pm 0.47 \mu \mathrm{g} / \mathrm{kg}$, respectively. The total and specific toxicities of each organ extracts were calculated as shown in Table 1.

Hemolytic activity. The hemolytic activity of $A$. stellatus toxin induced moderate level of hemolysis against the human erythrocytes and it was expressed as $\mu \mathrm{g} / \mathrm{mL}$ of toxin. Fig. 1 present the hemolytic activity of toxins and the dose response curve increased hemolysis, when the concentration of the toxin increased. The maximum and minimum hemolytic activity was recorded in the gonads and muscle toxin, respectively.

Brine shrimp lethality assay. Fig. 2 and Table 2 depicted the brine shrimp lethality. The provoked $\mathrm{LC}_{50}$ value was

Table 1. Steps of partial purification and crabs toxicity $\left(\mathrm{LD}_{50}\right)$ level of toxin separated from different organs of puffer fish $A$. stellatus

\begin{tabular}{lccc}
\hline \hline \multirow{2}{*}{ Step } & \multicolumn{3}{c}{ Crabstoxicity $(\mathrm{mg} / \mathrm{kg})$} \\
\cline { 2 - 4 } & Muscle & Ovary & Liver \\
\hline Defatting & $49.78 \pm 0.12$ & $38.07 \pm 1.14$ & $44.88 \pm 0.14$ \\
Charcoal & $47.22 \pm 0.33$ & $37.00 \pm 0.03$ & $44.61 \pm 0.40$ \\
Bio-gel & $45.42 \pm 0.47$ & $34.69 \pm 0.11$ & $42.84 \pm 0.28$ \\
\hline
\end{tabular}

observed by the different organ (muscles, liver and gonads) toxin of $A$. stellatus after $24 \mathrm{hr}$ of exposure when compared to the control.

Antiproliferative activity of MTT and apoptosis assays. The antiproliferative effect of puffer fish toxin on HeLa cell lines are presented in Fig. 3 and $\left[{ }^{3} \mathrm{H}\right]$ thymidine incorpora-

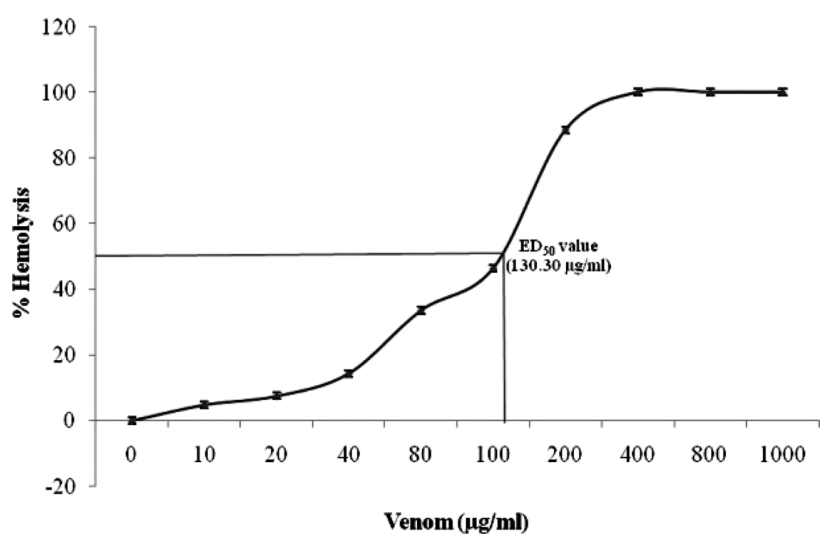

Fig. 1. Hemolytic activity of $A$. stellatus toxin on human erythrocytes. Human erythrocytes were incubated with increasing doses of partially purified toxin for $60 \mathrm{~min}$. Release of hemoglobin was determined by measuring the absorbance at $540 \mathrm{~nm}$. Saline was used as a blank for the absorbance measurement. The $100 \%$ control for cell lysis was determined by addition of water values represent the mean $\pm \mathrm{SE}$ of three experiments.

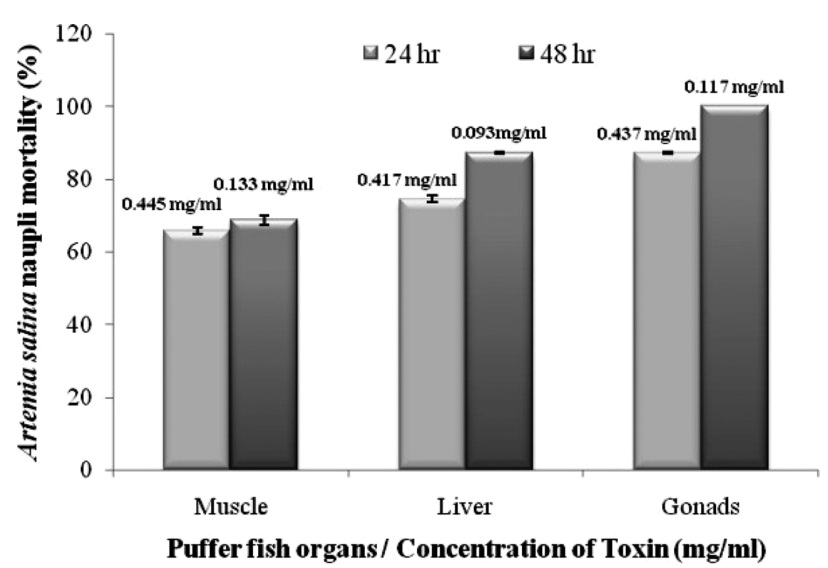

Fig. 2. Mortality of Artemia salina naupli (\%) after 24 and $48 \mathrm{hrs}$ of exposure to toxin extracts from $A$. stellatus.

Table 2. $24 \mathrm{hr}$ and $48 \mathrm{hr}$ exposed lethal concentration $\left(\mathrm{LC}_{50}\right)$ of puffer fish (A. stellatus) toxin extracts used against $A$. salina nauplii

\begin{tabular}{lcc}
\hline \hline Organs & $\mathrm{LC}_{50} 24 \mathrm{hr} /(\mathrm{mg} / \mathrm{mL})$ & $\mathrm{LC}_{50} 48 \mathrm{hr} /(\mathrm{mg} / \mathrm{mL})$ \\
\hline Muscle & $0.445 \pm 0.008$ & $0.133 \pm 0.001$ \\
Liver & $0.417 \pm 0.002$ & $0.093 \pm 0.006$ \\
Gonads & $0.437 \pm 0.006$ & $0.117 \pm 0.003$ \\
\hline
\end{tabular}




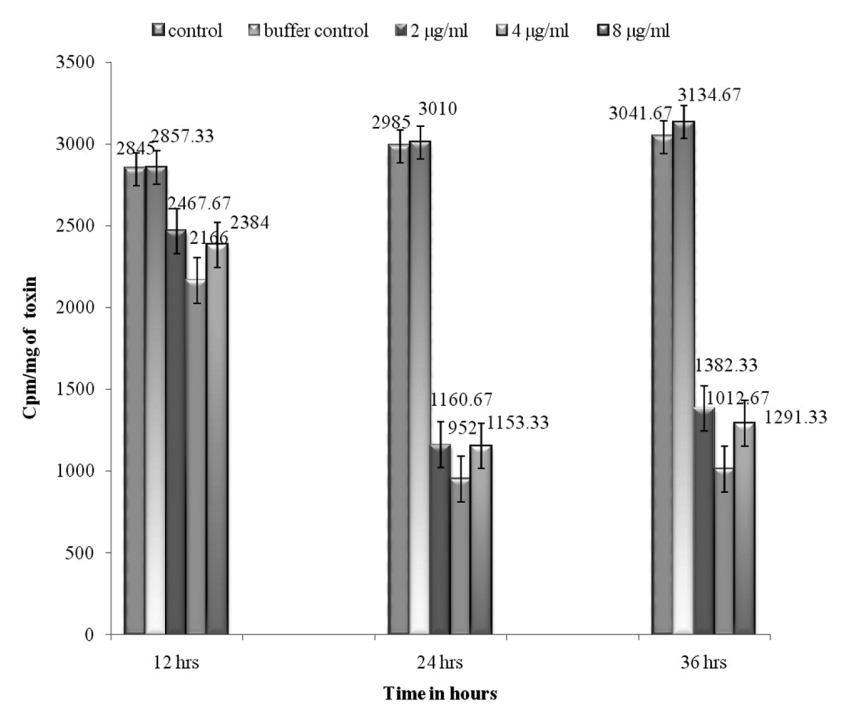

Fig. 3. Antiproliferative effect of $A$. stellatus toxin on HeLa cell lines.

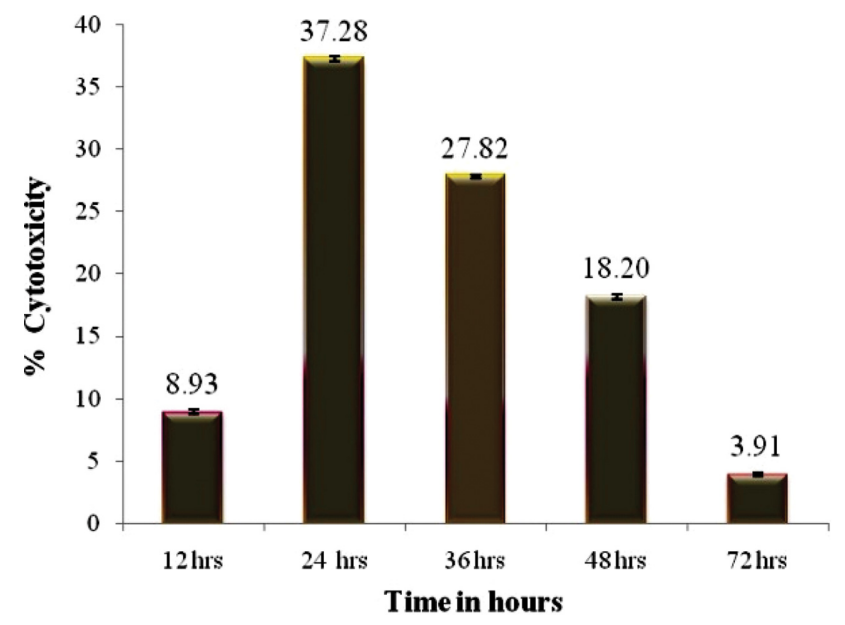

Fig. 4. MTT assay showing the cytotoxicity of $A$. stellatus toxin.

tion studies were conducted in three time points at 12, 24 and $36 \mathrm{hr}$. There was conspicuous inhibition of proliferation was observed at $24 \mathrm{hr}$ toxin treated cells. The cytotoxic effect was evaluated by the release of lactate dehydrogenase (LDH) from HeLa cells subsequent to treating with toxin at various time points, did not exceed $37.28 \%$, which suggests that the antiproliferative effect is by induction of apoptosis in treated cells (Fig. 4). The treated monolayer of HeLa cells were contained more apoptotic cells when compared to untreated monolayer (Fig. 5). There was characteristic nuclear fragmentation of nuclei in treated HeLa cells, whereas; the untreated control cells did not show any nuclear fragmentation. The apoptotic cells displayed the characteristic features of reduced size, intense fluorescence of condensed nuclear chromatin and formation of membrane blebs. Similar results were observed with the same dose of the toxin

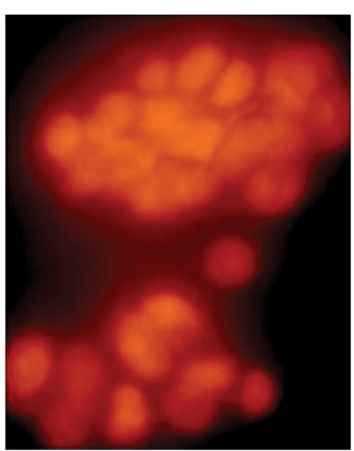

Untreated HeLa cells

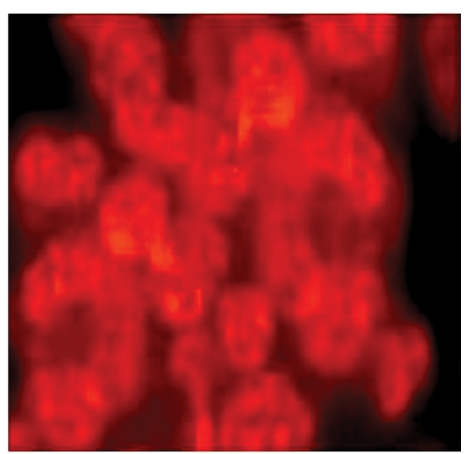

Toxin treated HeLa cells
Fig. 5. The morphological assessment of nuclear localization of HeLa cells by propidium iodide staining.

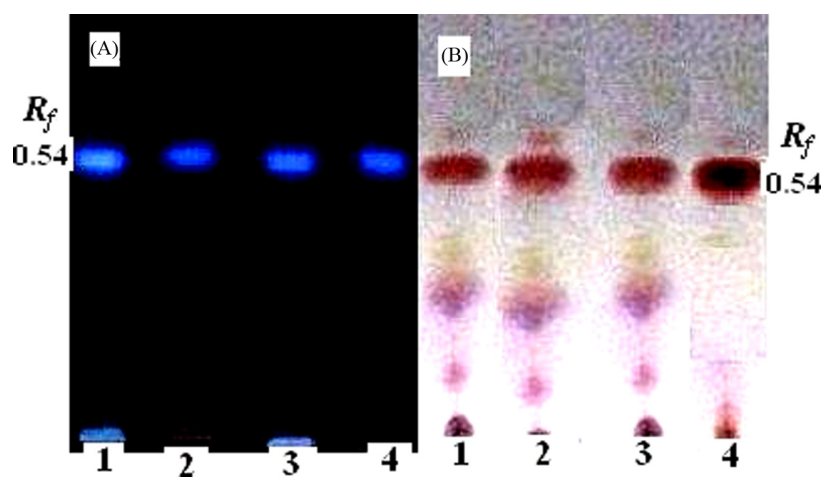

Fig. 6. TLC of the TTX fraction from different organs of A. stellatus, Lane 1: Muscle, Lane 2: Ovary and Lane 3: Liver, (A) After development, toxin samples were heated for $10 \mathrm{~min}$ and visualized under UV light ( $365 \mathrm{~nm})$; and (B) after development, toxin samples were sprayed with $0.3 \%$ of ninhydrin solution.

extract on the HeLa cells.

TLC analysis. Fig. $6 \mathrm{~A}$ and $6 \mathrm{~B}$ showed that the same pattern of thin-layer chromatography (TLC) and visualized as a pink spot after spraying the plate with ninhydrin reagent with an $R_{f}$ (Relative factor) value of 0.54 corresponding to that of authentic TTX.

Quantification of TTX. Fig. 7 showed that the HPLC patterns of $A$. stellatus toxin and clearly revealed that the three very obvious peaks with retention times was obtained at $9.52,10.35$, and $12.47 \mathrm{~min}$ and which was conformed and named as TTX, 4-epiTTX and anhydro-TTX or anh-TTX.

\section{DISCUSSION}

Tetrodotoxin (TTX), a powerful and lethal poison is a sodium channel blocker. TTX has been used extensively to characterize sodium channels and to study their role in normal physiology and disease. In the present study, toxin dis- 

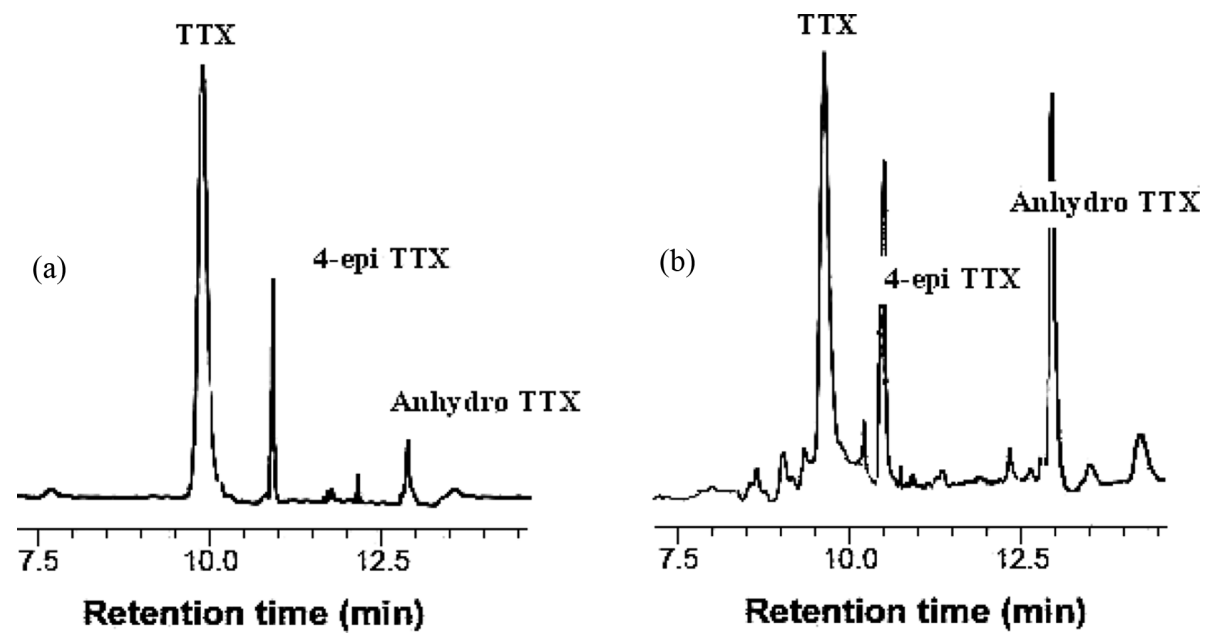

Fig. 7. HPLC analysis of TTX and its derivatives extracted from A. stellatus (A) and (B) authentic TTX: 1, TTX; 2, 4-epi-TTX; 3, anh-TTX.

tribution at the tissue level in A. stellatus (tetraodontidiforms) and considerable variation exists between and within species and several functional hypotheses about the distribution of TTX were suggested for the first time. Finally, TTX appears to play both an offensive and defensive role in the puffer fish and the best of our knowledge, this paper is the first report on the isolation and identification of biological and cytotoxic effects of toxin from $A$. stellatus. The results from the present study clearly suggested that the tissue specific distribution of TTX, 4-epiTTX and anhydro-TTX or anh-TTX in ovaries and livers were unequally distributed.

By crabs (Ocypode macrocera) bioassay method, it was detected that different organs of the puffer fish toxin showed different toxicities. The $\mathrm{LD}_{50}$ level of toxicity was estimated as $34.69 \pm 0.11 \mu \mathrm{g} / \mathrm{kg}$ for ovary toxin and followed by liver toxicity was more potent toxic level, whose toxicities were $42.84 \pm 0.28 \mu \mathrm{g} / \mathrm{kg}$ and $45.42 \pm 0.47 \mu \mathrm{g} / \mathrm{kg}$, respectively. After the injection of concentrated toxin extracts into their third walking legs, intense spasmodic movement was visible and the legs turned tremble with involuntary lateral movements, appendages were shivering and showed a stiffness change in carapace color, complete loss of control, paralysis, and respiratory distress was observed prior to death. Some of these symptoms suggested that the neurotoxic effects are convulsions, leads to paralytic, foaming, colour changes, restlessness and mortality.

Presently, massive active toxin from puffer fish and these toxic polypeptides affects the muscular cells producing contractions on the crab legs. This result was in concurrence with Ali (24) and Béress and Zwick (25), who reported that the puffer fish toxins were concentrated in the ovaries and liver, with lesser amounts present in the digestive tract and skin. Similarly, Béress and Béress (26) reported that the neurotoxic polypeptides act at the level of sodium channels, and could maintain their structural stability and functionality during the purification process by forming disulphide bridges. Moreover, the ovary and other genital organs of neurotoxin containing vertebrates such as California newt Taricha torosa (27), flatworm Planocera multitentaculata (15), and sea anemone Stichodactyla mertensii and S. haddoni (28) were reported that they are highly toxic. In addition, the results of the present study revealed that the isolated neurotoxin from each organ of puffer fish was defatted with $\mathrm{CH}_{2} \mathrm{Cl}_{2}$ and purified using activated charcoal followed by gel filtration using Bio-Gel P-2 column chromatography. It was found that after gel filtration, there was some loss in toxicity in the case of muscle and liver obtained during processing, but in the case of ovary (gonads), it was increased.

The results of the present study exposed that the maximum and minimum hemolytic activity in the gonads and skin toxin, respectively. These types of primary techniques very useful to testing the normal cell line in laboratory condition. The results of the present study suggested that the maximum $130.30 \mu \mathrm{g} / \mathrm{mL}$ amount of tetrodotoxin produced $50 \%$ hemolysis of the erythrocytes present in $200 \mathrm{~mL}$ of a $1 \%$ suspension of these cells, and $286.60 \mu \mathrm{g} / \mathrm{mL}$ causing $100 \%$ hemolysis. This observation is in agreement with the finding for toxin from Bartholomea annulata, in which hemolysis was induced in mouse erythrocytes (29). According to Gleibs et al. (30) has been reported that the hemolytic unit (HU) as the amount of material necessary to produce $50 \%$ hemolysis in human erythrocytes within $4 \mathrm{hr}$ incubation of PTX from Palythoa and other marine animal. Similarly, Gleibs and Mebs (31) quantified one hemolytic unit (HU) in $0.4 \mu \mathrm{g}$ of PTX, but due to the different sensitivity of mammalian erythrocytes to PTX (32); this value should probably be referred only to human red cells. A similar definition of the HU, without references to the time of incubation, is also given by Lenoir et al. (33) reported with mouse red cells. Taniyama et al. (34) quantified PTX effects with the percentage of hemolysis, calculated with the ratio between the value measured for a sample and that 
registered for the total hemolysis.

The brine shrimp lethality assay represents a rapid, inexpensive and simple bioassay for testing bioactivity of toxin extracts which is correlated reasonably well with cytotoxicity and anti-tumor properties (35). Only a few species were lethal activity against the brine shrimp bioassay at 10 and $100 \mu \mathrm{g}$ extract per $\mathrm{mL}$. A lower relationship between the shrimp bioassays and cytotoxicity assays was found. However, most of the marine animals presented toxicity in some of the bioassay at $1000 \mu \mathrm{g} / \mathrm{mL}$ in a way that was consistent with the cytotoxicity results. As anticipated, lethality was increased with increased toxin concentrations and these results were in agreement with the brine shrimp lethality of puffer fish toxin activities observed using Meyer et al. (19) method. In the $A$. salina lethality bioassay, the TTX extracts of different organs such as muscles, gonads, and liver belonging to puffer fish were the most toxic and $\mathrm{LC}_{50}$ values of the brine shrimp lethality. No mortality was observed in the wells to which Milli-Q water was added. The acute and chronic $\mathrm{LC}_{50}$ value for potassium dichromate was estimated to be 530 and 20 ppm respectively.

The $\mathrm{LC}_{50}$ values are obtained from different organs (muscles, liver and gonads) of puffer fish toxin after $24 \mathrm{hr}$ of exposure were $0.445 \pm 0.008,0.417 \pm 0.002$ and $0.437 \pm$ $0.006 \mathrm{mg} / \mathrm{mL}$, respectively. The toxicity of these puffer fish toxins was confirmed after a longer exposure time ( $48 \mathrm{hr}$ ), as evidenced by the $\mathrm{LC}_{50}$ values (Table 2). Recently, Lopes et al. (36) studied that the maximum sensibility of brine shrimp lethality was reached after $48 \mathrm{hr}$ of longer exposure. High incidence of toxicity in sponges and echinoderms seems have been an effective defense mechanisms against many predatory fishes, which increases closer to the tropics (almost $100 \%$ of all species tested) (37). In this study, different organs tetrodotoxin extract of $A$. stellatus, has good quality for the production of bioactive compounds. The degree of lethality was found to be directly proportional to the concentration of the toxin extract and the maximum mortalities took place at a concentration of $1000 \mu \mathrm{g} / \mathrm{mL}$, whereas least mortalities were at $10 \mu \mathrm{g} / \mathrm{mL}$ concentration. This significant lethality of different organ of puffer fish toxin to brine shrimp is an indicative of the presence of potent cytotoxic components which deserves further investigation.

The antiproliferative effect of puffer fish toxin on HeLa cell lines and $\left[{ }^{3} \mathrm{H}\right]$ thymidine incorporation studies were conducted in three time points at 12, 24 and $36 \mathrm{hr}$. The present result was expressed as counts of $\left[{ }^{3} \mathrm{H}\right]$ thymidine incorporated into the actively proliferating cells per min per $\mathrm{mg}$ toxin of the cell mass. The cells control and PBS control shows the maximum counts of $\left[{ }^{3} \mathrm{H}\right]$ thymidine (around 3135 $\mathrm{cpm} / \mathrm{mg}$ peptides) when compared to the treated cells. Dose dependent study shows that $4 \mu \mathrm{g} / \mathrm{mL}$ of toxin investigated the maximum inhibition $(952 \mathrm{cpm} / \mathrm{mg}$ peptide for $\mathrm{HeLa}$ cells, respectively) and the same doses level $(4 \mu \mathrm{g} / \mathrm{mL})$ was did not confirm any cytotoxicity of the normal human lym- phocytes. The result of the present study revealed that the puffer fish toxin could be found in some of valuable substances and presents a great potential as an anti-tumor agent. Hence this level of dose alone was used for further studies. However, puffer fish toxin was found to have a selective sensitivity of cancer cells. Here, the question arises, whether the antiproliferative effect is by apoptotic or necrotic pathway. Monolayer of HeLa cells were treated with fish toxin peptide $(4 \mu \mathrm{g} / \mathrm{mL})$ and the extent of apoptosis were assessed by propidium iodide staining. This was confirmed by the MTT assay, the release of LDH is considered to be of necrotic pathway and the treated cells showing very less levels of LDH after $24 \mathrm{hr}$, suggests that the event of cell death by apoptosis. According to this result, the regulation of apoptosis in both normal and malignant cells has become an area of extensive study in cancer research (38). Herr and Debatin (39) reported many agents that induce apoptosis are often found to target the mitochondria and promote the activation of caspases, which are important proteolytic enzymes responsible for the execution of apoptosis. Correspondingly, Lipps (40) reported that the two protein fractions from snake venom, Atroporin and Kaotree on SP/2 cell line and Gerl and Vaux (41) suggested that a cancer cell treated with a potentially lethal toxin will not die because of the direct effects of toxins, but will activate its suicide mechanism to die earlier by apoptosis. Thus, in light of the previous findings, it is evident that puffer fish toxin induces apoptosis selectively in cancer cells.

The isolated puffer fish toxins were characterized by thinlayer chromatography and results showed that the same pattern and visualized as a pink spot after spraying the plate with ninhydrin reagent with an $R_{f}$ (Relative factor) value of 0.54 corresponding to that of authentic TTX (Fig. 6B). In the case of muscles, gonads, and liver, an additional two spot with $R_{f}$ values of 0.36 and 0.23 were appeared, coinciding with that of anh-TTX. As seen in Fig. 6A, the TLC patterns of the isolated puffer fish toxin were detected under UV light illumination $(365 \mathrm{~nm})$ as one clear fluorescent blue spot with an $R_{f}$ value of 0.54 , when sprayed with $10 \%$ of $\mathrm{KOH}$, suggesting that these spots were associated with TTX. The present results of toxin agreed well with those obtained by Ali (24) on the liver toxin extracted from puffer fish Arothron hispidus. Freeman and Turner (42) reported that the level of toxicity is similar in tetrodotoxin and MTX \& TTX while using the thin layer chromatography plates. The positive reactions to all the reagents were obtained for both toxins, and the colours produced were the same for the polychromatic sprays (e.g. ninhydrin-dicylohexylamine). This finding is corroborated by reports from Croft and Howden (43) described that both TTX and MTX gave positive reactions for sodium ions. The MTX and TTX had the similar $R_{f}$ values (0.4) in n-butanol-acetic acid-water, whereas saxitoxin was separated $R_{f}$ values were observed at 0.23 and isopropanol-acetic acid-water MTX and TTX had $R_{f}$ values 
of 0.52 and 0.53 , respectively. TTXs were the major toxins in all tissues of all specimens tested in this study, and MTX were also detected in almost all tissues as the minor components.

The quantification of $A$. stellatus toxin clearly revealed that the three clear peaks with retention times was obtained at 9.52, 10.35, and $12.47 \mathrm{~min}$ (Fig. 7A), which were in good conformity with those of standard TTX, 4-epiTTX and anhydro-TTX or anh-TTX (Fig. 7B), respectively. Total toxicity of the three components calculated from their specific toxicities coincided well with the toxicity determined by brine shrimp and crabs bioassay in A. stellatus. The present finding suggests that most of the paralyzing activity could be due to the TTX compounds excreted from the different organs of puffer fish and it was noted that TTX as a major toxin and anh-TTX as a minor toxin levels. Therefore, at least one of these compounds was showed presence of toxicity in the crabs and brine shrimp assay. In conclusion, A. stellatus toxin was containing several factors with antiproliferative and biological activity, in different organs. The A. stellatus toxin has been potent cytolytic activity and the viability of cancer cells was dose dependent manner against HeLa cells. The hemolytic activity and cell line studies have been pointed out the cytolytic activity of the tetrodotoxin and the present results open up new vistas for research on the effects of $A$. stellatus toxin on cytolytic activities. These findings suggested that the isolated puffer fish toxin might play an important role in TTX accumulation/production in $A$. stellatus. However, the potential sources of TTX in puffer fish still need intensive study. Therefore, further studies are needed in order to purify the active compounds to identify their chemical nature and to evaluate their potential as novel drug from the puffer fish toxin. Additionally, we propose a bio-guided isolation of the new compounds responsible for the presence of biological activity and colon cancer-preventive agent on experimental higher and lower animal models, with the purpose of being used as pharmaceutical entities or for the standardization of marine natural biomedicines.

\section{ACKNOWLEDGEMENTS}

The authors' thanks the authorities of Annamalai University, Tamil Nadu, India, for their support. We also thank the Ministry of Earth Science Govt. of India (MOES), for funding the project under OASTC, programme.

\section{CONFLICT OF INTEREST STATEMENT}

The author declares that there are no conflicts of interest.

\section{REFERENCES}

1. WHO (2008) The World Health Report, World Health Organi- zation, Geneva.

2. Zong, A., Cao, H. and Wang, F. (2012) Anticancer polysaccharides from natural resources: a review of recent research. Carbohydr. Polym., 90, 1395-1410.

3. Newman, D.J. and Cragg, G.M. (2012) Natural products as sources of new drugs over the 30 years from 1981 to 2010. J. Nat. Prod., 75, 311-335.

4. Dhawan, A., Kayani, M.A., Parry, J.M., Parry, E. and Anderson, D. (2003) Aneugenic and clastogenic effects of doxorubicin in human lymphocytes. Mutagenesis, 18, 487-490.

5. Anastyuk, S.D., Shevchenko, N.M., Ermakova, S.P., Vishchuk, O.S., Nazarenko, E.L., Dmitrenok, P.S. and Zvyagintseva, T.N. (2012) Anticancer activity in vitro of a fucoidan from the brown alga Fucus evanescens and its low molecular fragments, structurally characterized by tandem mass spectrometry. Carbohydr. Polym., 87, 186-194.

6. Kong, C.S., Kim, J.A., Yoon, N.Y. and Kim, S.K. (2009) Induction of apoptosis by phloroglucinol derivative from Ecklonia cava in MCF-7 human breast cancer cells. Food Chem. Toxicol., 47, 1653-1658.

7. Lordan, S., Ross, R.P. and Stanton, C. (2011) Marine bioactives as functional food ingredients: Potential to reduce the incidence of chronic diseases. Mar. Drugs, 9, 1056-1100.

8. da Rocha, A.B., Lopes, R.M. and Schwartsmann, G. (2001) Natural products in anticancer therapy. Curr. Opin. Pharmacol., 1, 364-369.

9. WHO (2006) The World Health Report - Health systems: improving performance, World Health Organization. Geneva.

10. Kao, C.Y. (1966) Tetrodotoxin, saxitoxin and their significance in the study of excitation phenomenon. Pharmacol. Rev., 18, 997-1049.

11. Chau, R., Kalaitzis, J.A. and Neilan, B.A. (2011) On the origins and biosynthesis of tetrodotoxin. Aquat. Toxicol., 104, 61-72.

12. Froese, R. and Pauly, D. (2008) FishBase, World Wide Web electronic publication.

13. Veeruraj, A., Arumugam, M., Ajithkumar, T. and Balasubramanian, T. (2011) Distribution of Tetraodontiformes (Family: Tetraodontidae) along the Parangipettai Coast, Southeast coast of India. Zootaxa, 3015, 1-12.

14. Yu, C.F. and Yu, P.H. (2002) The annual toxicological profiles of two common puffer fish, Takifugu niphobles (Jordan and Snyder) and Takifugu alboplumbeus (Richardson), collected along Hong Kong coastal waters. Toxicon, 40, 313-316.

15. Miyazawa, K., Jeon, J.K., Maruyama, J., Noguchi, T., Ito, K. and Hashimoto, K. (1986) Occurrence of tetrodotoxin in the flatworm Planocera multitentaculata. Toxicon, 24, 645-650.

16. Kotaki, Y., Osshima, Y. and Yasumoto, T. (1981) Analysis of paralytic shellfish toxins of marine snails. Bull. Japan. Soc. Sci. Fish, 47, 943-946.

17. Lehman, J.T. (1980) Release and cycling of the nutrients between planktonic algae and herbivores. Limnol. Oceanogr., 25, 620-632.

18. Zhu, W.L., Lan, H., Park, I.S., Kim, J.I., Jin, H.Z., Hahm, K.S. and Shin, S.Y. (2006) Design and mechanism of action of a novel bacteria-selective antimicrobial peptide from the cell penetrating peptide Pep-1. Biochem. Biophys. Res. Commun., 349, 769-774.

19. Meyer, B.N., Ferrigni, N.R., Putnam, J.E., Jacobson, L.B., 
Nichols, D.E. and McLaughlin, J.L. (1982) Brine shrimp: a convenient general bioassay for active plant constituents [J]. Planta Med., 45, 31-34.

20. Finney, D.J. (1971) Probit Analysis (3rd edition), Cambridge University Press, Cambridge, p. 333.

21. Mosmann, T. (1983) Rapid Colorimetric Assay for Cellular Growth and Survival: Application to Proliferation and Cytotoxicity Assays. J. Immunol. Methods, 65, 55-63.

22. Nakamura, M. and Yasumoto, T. (1985) Tetrodotoxin derivatives in puffer fish. Toxicon, 23, 271-276.

23. Hanifin, C.T., Yotu-Yamashita, M., Yasumoto, T., Brodie, E.D., III. and Brodie, E.D., Jr. (1999) Toxicity of dangerous prey: Variation of tetrodotoxin levels within and among populations of the newt Taricha granulose. J. Chem. Ecol., 25, 2161-2175.

24. Ali, A.E. (1996) Toxin composition in liver of the pufferfish Arothron hispidus from the Aqaba Gulf, Red Sea. J. Egypt Ger. Soc. Zool., 20, 67-79.

25. Béress, L. and Zwick, J. (1980) Purification of two crab-paralyzing polypeptides from the sea anemone Bolocera tuediae. Mar. Chem., 8, 333-338.

26. Béress. L., Zwick, J. and Béress, R. (1984) Biologically active compounds from marine invertebrates. Nova Acta Leopold., 56, 153-159.

27. Mosher, H.S., Fuhrman, F.A., Buchwald, H.D. and Fischer, H.G. (1964) Tarichatoxin-tetrodotoxin: a potent neurotoxin. Science, 144, 1100-1110.

28. Veeruraj, A., Arumugam, M., Ajithkumar, T. and Balasubramanian, T. (2008) Isolation and biological properties of neurotoxin from sea anemone (Stichodactyla mertensii, S. haddoni). Internet J. Toxicol., 5, 1-10.

29. Santamaría, A., Sánches-Rodríguez, J., Zugasti, A., Martínez, A., Galván-Arzate, S. and Segura-Puertas, L. (2002) A venoms extract from the sea anemone Bartholomea annulata produces haemolysis and lipid peroxidation in mouse erythrocytes. Toxicology, 173, 221-228.

30. Gleibs, S., Mebs, D. and Werding, B. (1995) Studies on the origin and distribution of palytoxin in a Caribbean coral reef. Toxicon, 33, 1531-1537.

31. Gleibs, S. and Mebs, D. (1999) Distribution and sequestration of palytoxin in coral reef animals. Toxicon, 37, 1521-1527.

32. Habermann, E. (1989) Palytoxin acts through $\mathrm{Na}^{+}, \mathrm{K}^{+}$-ATPase. Toxicon, 27, 1171-1187.

33. Lenoir, S., Ten-Hage, L., Turquet, J., Quod, J.P., Bernard, C. and Hennion, M.C. (2004) First evidence of palytoxin analogues from an Ostreopsis mascarenensis (Dinophyceae) benthic bloom in southwestern Indian Ocean. J. Phycol., 40, 1042-1051.

34. Taniyama, S., Mahmud, Y., Tanu, M.B., Takatani, T., Arakawa, O. and Noguchi, T. (2001) Delayed hemolytic activity by the freshwater puffer Tetraodon sp. toxin. Toxicon, 39, 725-727.

35. McLauglin, J.L., Chang, C.J. and Smith, D.L. (1993) Simple bench-top bioassays (brine shrimp and potato discs) for the discovery of plant antitumour compounds in Human Medicinal Agents from Plants. (Kinghorn, A.D. and Balandrin, M.F. Ed.). ACS Symposium 534, American Chemical Society, Washington, D.C., pp. 112-137.

36. Penha-Lopes, G.P., Torres, P., Cannicci, S., Narciso, L. and Paula, J. (2011) Monitoring anthropogenic sewage pollution on mangrove creeks in southern Mozambique: A test of Palaemon concinnus Dana, 1852 (Palaemonidae) as a biological indicator. Environ. Pollut., 159, 636-645.

37. Bakus, G.J. and Green, G. (1974) Toxicity in sponges and holothurians: A geographic pattern. Science, 185, 951-953.

38. Johnstone, R.W., Ruefli, A.A. and Lowe, S.W. (2002) Apoptosis: a link between cancer genetics and chemotherapy. Cell, 108, 153-164.

39. Herr, I. and Debatin, K.M. (2001) Cellular stress response and apoptosis in cancer therapy. Blood, 98, 2603- 2614.

40. Lipps, B.Y. (1999) Novel snake venom proteins cytolytic to cancer cells in vitro and in vivo systems. J. Venom. Anim. Toxins, 5, 172-183.

41. Gerl, R. and Vaux, D.L. (2005) Apoptosis in the development of cancer. Carcinogenesis, 26, 263-270.

42. Freeman, S.E. and Turner, R.J. (1970) Maculotoxin, a potent toxin secreted by octopus, Maculosus Hoyle. Toxicol. Appl. Pharmacol., 16, 681-690.

43. Croft, J.A. and Howden, M.E. (1972) Chemistry of maculotoxin, a potent neurotoxin isolated from Hapalochlaena maculosa. Toxicon, 10, 645-651. 